\section{Mount St Helens 40 years on}

On the 18 May 1980, Mt St Helens, a prominent volcano in Washington, USA, exploded. The eruption, which killed 57 people and caused widespread damage to forests and travel infrastructure, remains the largest volcanic event in the contiguous US states for over 100 years. Carefully documented changes in the volcano's behaviour and appearance over the few months prior to the eruption continue to provide a legacy dataset, which has informed our understanding of volcanic systems worldwide for almost 40 years.

Prior to the 1980 eruption, Mt St Helens had lain dormant for over 100 years, displaying few signs of volcanic activity since its last eruptive episode in 1857. Nevertheless, the potential for large, destructive eruptions at Mt St Helens was well known. For example, Katharine Cashman, Professor of Volcanology at the University of Bristol, UK, comments that, by 1978, Mt St Helens had been identified as "the most active volcano in the Cascade Range, and it was possible that it would erupt before the end of the [twentieth] century". Thus, when the volcano started to show signs of reawakening, which began with a series of small earthquakes in March 1980, it drew the attention of the United States Geological Survey (USGS) who set up the Coldwater II observation post approximately $8 \mathrm{~km}$ north of the volcano.

From the end of March to the start of May 1980, the frequency of high magnitude ( $>4$ ) earthquakes increased from one event on 20 March to approximately eight per day in the week preceding the 18 May eruption (Harris, S. L. Fire Mountains of the West: the Cascade and Mono Lake Volcanoes 201-228; Mountain Press, 1988). In addition, phreatic eruptions (steam explosions resulting from sudden heating of groundwater) initiated towards the end of March and continued through April and into May, leading to the formation of a new crater

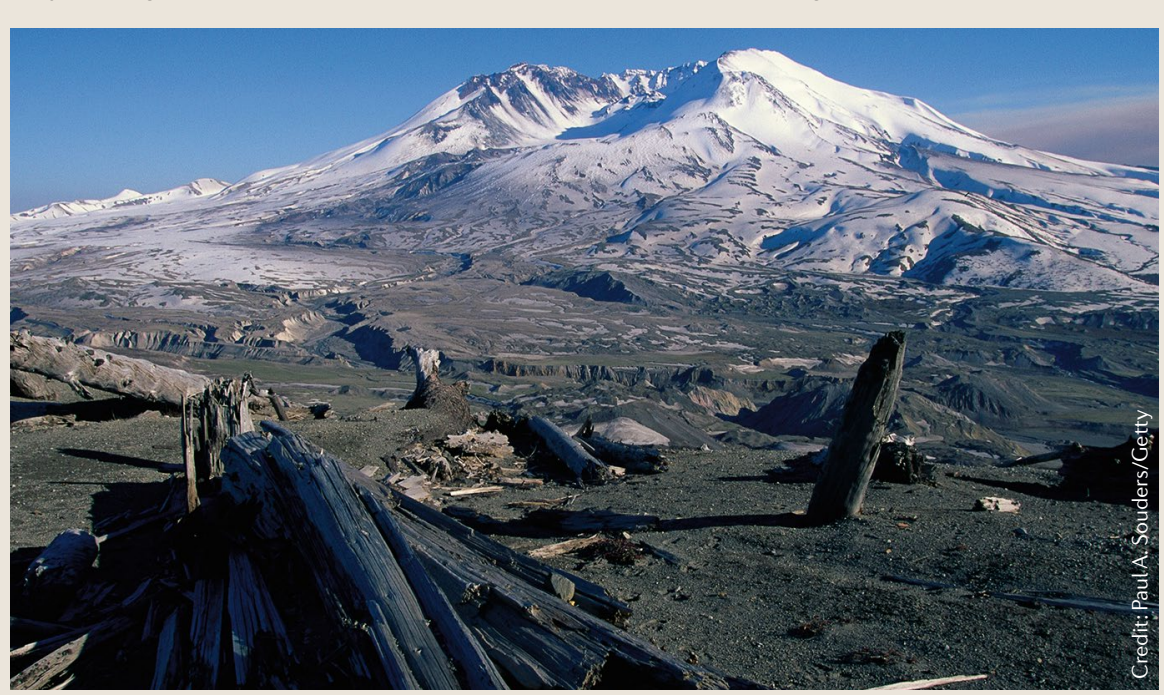

unable to comprehend the scope of events occurring before our eyes."

Following the initial lateral blast, the 18 May eruption "followed a more 'normal' pattern, with an upward-directed volcanic plume that was then blown to the east by strong westerly winds, depositing volcanic ash across Washington and parts of Idaho and Montana," comments Cashman. Smaller explosive eruptions continued throughout 1980 and eventually transitioned into a period of effusive lava emission and lava dome growth within the newly formed volcanic crater. Activity ceased in 1986 , and although eruptions were observed between 2004 and 2008, these were not explosive.

$\mathrm{Mt}$ St Helens represents just one of 25 volcanic regions that are currently monitored by $\mathrm{CVO}$ and, importantly, it is not the only volcano in the western USA that has the potential to produce large, explosive volcanic eruptions. In fact, the 1980 eruption of Mt St Helens was relatively small compared with the largest, but extremely infrequent, eruptions that have occurred at some volcanoes along the Cascade Range (such as the 7,700 ka eruption of Crater Lake, which was $\sim 50$ times the size of the Mt St Helens 1980 event). Seth Moran, chief scientist at CVO, states that "we primarily concern ourselves with nine volcanic systems [Mt Baker, Glacier Peak, Mt Rainier, Mt St Helens, Mt Adams, Mt Hood, Three Sisters, Newberry and Crater Lake] because of their hazard (eruption frequency, explosivity, etc.) and/or society's exposure to the hazards." CVO monitors each of these systems closely and provides hazard training for park officials, interpreters and the news media to ensure that hazards posed by each volcano are accurately communicated to all.

In the 1970 s and early 1980 , volcano monitoring was in its infancy. At the time of the 18 May eruption only a single seismometer existed within 30 miles of $\mathrm{Mt} \mathrm{St} \mathrm{Helens.} \mathrm{However,} \mathrm{in}$ the 40 years since, $\mathrm{Mt}$ St Helens has become the 'gold standard' for volcano monitoring in the Cascades with "an excellent network of realtime seismometers and GPS stations," states Moran. While there is always a possibility that Mt St Helens will erupt explosively again, smaller, less-destructive eruptions are more likely.

The 1980 eruption of Mt St Helens highlighted the potential dangers of active volcanoes and provided crucial information for volcanologists studying volcanic systems worldwide. Data collected during, and after, the 18 May eruption has "provided a baseline for other volcanic studies," comments Cashman. Furthermore, the 18 May event enabled, for the first time, scientists to observe the reawakening of a volcano with modern monitoring techniques such as seismometers and satellite imagery, giving insights into the precursory signals (for example, heightened seismicity and accelerating deformation) that sometimes precede large explosive eruptions.

Matthew Gleeson 